\title{
Gender in Tourism Research: Perspectives from Latin America
}

\begin{tabular}{|r|l|}
\hline Journal: & Tourism Review \\
\hline Manuscript ID & TR-02-2017-0021.R2 \\
\hline Manuscript Type: & Literature Review \\
\hline Keywords: & $\begin{array}{l}\text { Gender, Tourism, Research, Latin America, Bibliometric analysis, } \\
\text { Knowledge production }\end{array}$ \\
\hline \multicolumn{2}{|l}{} \\
\hline
\end{tabular}




\section{Abstract}

Purpose: To examine the knowledge production on tourism gender research in Latin America and to reflect on the main challenges faced by the subfield.

Design / Methodology I Approach: The study conducts a bibliometric analysis of the journal articles on tourism gender research in the largest scientific databases in Latin America: Redalyc, Scielo and Latindex. The paper examines variables such as year of publication, journal, authors, affiliation, types of articles, research topics, methodologies and geographical location of fieldwork.

Findings: The study identified 153 gender aware papers from 70 journals for the period 2001-2015. The leading countries in the subfield are Brazil, Mexico and Argentina. The majority of papers are empirical and have a local scope. The main theoretical approaches derive from sociological and anthropological perspectives with a predominance of qualitative methodologies. There is a need to strengthen the theoretical and epistemological frameworks and increase international collaboration for knowledge exchange among tourism gender scholars.

Research limitations / implications: The bibliometric analysis was limited to indexed journals with online access. It focused on academic articles and excluded research notes, book reviews and conference proceedings.

Originality I Value: Since the main working languages of scientific production in Latin America are Spanish and Portuguese, this is the first attempt to make tourism gender research from this region visible for the predominantly Anglophone tourism academy, with the intention of identifying common challenges.

Keywords: Gender, Tourism, Research, Latin America, Bibliometric Analysis, Knowledge Production

Article classification: Literature review 


\section{Introduction}

In the past decade, international, intra-regional and domestic travel in Latin American countries have experienced continuous growth (UNWTO, 2016; Ghimire, 2013). This growth has resulted from policies favouring tourism as a development strategy, evidencing the region's integration into the global economy (Capanegra, 2008; Berger, 2006). Tourism and development are transversal processes constructed out of asymmetric power relations between countries, organizations and groups of people with different positions in society. These processes have transformed territories and traditional activities, modifying the identities of social actors (Bergareche and Vargas, 2010). The complexity of tourism processes contrasts with the reductionist perspectives prevalent in tourism scholarship (Serrano-Barquín, 2008; Salazar, 2006).

A complex aspect that has received scant attention refers to the gender dimensions of tourism development (Duffy et al., 2015; Ferguson, 2011; Díaz-Carrión, 2010-2012). For the past 30 years, the macrostructural adjustments promoted by neoliberal policies in Latin America have accelerated women's integration into the labour market and the public sphere, as strategies for economic survival (Carosio, 2012, p.11). Tourism is one of the sectors that has absorbed women's labour. In Latin America and the Caribbean, women account for $60 \%$ of the total workforce in the hotel and restaurant sectors (UNWTO, 2011). This pattern has made sustainable tourism with gender equality a key challenge for the countries in the region (ECLAC, 2016).

The aim of this paper is two-fold: first, to identify the main aspects of knowledge production on tourism and gender in Latin America through a bibliometric analysis. Second to reflect on the common challenges of the subfield and identify areas for international collaboration.

\section{Tourism and gender research in Latin America}

In the 1960s, national public institutions began to promote tourism research in Latin America, aided by international training programmes created by the UN World Tourism Organization and the Organization of American States. The growth of higher education in the 1970s led to an increase in tourism academic research. The majority of tourism schools and faculties focused on technical training towards the operation of tourism-oriented businesses and services. Despite the importance of tourism activities in the region, the lack of research funding has limited the perspectives for a well-rounded academic production (GuevaraRamos et al., 2006).

Previous reviews on tourism academic production in Latin America have identified the evolution of research from systemic and industrial analysis of tourism with practical applications towards development, planning and training in the 1960s and 1970s, to more hypothetical-deductive approaches, influenced by Marxist, functionalist and critical theories in the 1980s (Schlüter and Bertoncello, 2010; Guevara-Ramos et al., 2006). Since the 1990s, there has been a focus on the environment, sustainability, and social and ethical values (Martínez, 2005), but scant attention has been given to the gender dimensions of tourism (Díaz Carrión, 2012). 
The links between gender and tourism were brought to the international research agenda in the mid-1990s (Sinclair, 1997; Swain, 1995; Kinnaird and Hall, 1994; Norris and Wall, 1994). The subfield has examined women's contributions as producers and consumers of tourism (Swain and Momsen, 2002; Apostolopoulos et al., 2001) and the gendered imagery of tourism promotion (Pritchard and Morgan, 2000). More recently, studies have documented inequalities that disproportionally affect women in tourism employment (Ferreira and Ramos, 2016; Huete et al., 2016; Baum, 2013); and discussed the links between tourism, gender and development (Ferguson and Moreno, 2015; Phommavong and Sörensson, 2014; Tucker and Boonabaana, 2012).

Influenced by the Anglophone academies, tourism gender studies emerged at the beginning of the $21^{\text {st }}$ century in Latin America, with a strong focus on the gendered impacts of tourism development in host communities (Vizcaino-Suárez et al., 2016). Feminist and gender scholars have sought to make gender and power relations visible in a region characterised by social, political and economic inequalities (Díaz-Carrión, 2012; Bergareche and Vargas, 2010). Despite these efforts, tourism gender knowledge produced in Latin America remains marginal both within the region and abroad. Regionally, the predominance of neo-positivist traditions that respond to industrial and technological needs has relegated critical knowledge production (Castillo and Panosso, 2011). The language barrier, lower levels of research internationalization (Pearce, 2013) and Eurocentric traditions (Cohen and Cohen, 2015) have rendered Latin American tourism scholarship imperceptible for the predominantly Anglophone academies.

Attempts to examine the evolution of the subfield have focused on qualitative reviews both in the Anglophone academies (Swain, 2005; Hall et al., 2003; Gibson, 2001) and in the IberoAmerican region (Vizcaino-Suárez et al., 2016). Figueroa-Domecq et al. (2015) undertook the first bibliometric analysis of tourism gender research, identifying relevant journal articles over the period 1985 to 2012, in the Scopus and ISI Web of Knowledge (WoK) databases. Small et al. (2017) conducted a bibliometric analysis of the top-ranked tourism and hospitality journals indexed in Scopus, for the period 2005 to 2014. Both studies selected databases that mostly capture Anglophone publications, limiting the geographic and linguistic diversity of the results.

This study adds to the efforts of examining the trends in tourism gender research, by overtaking a bibliometric analysis of the scholarly production in Latin America, where the main working languages are Spanish and Portuguese. From an academic standpoint, the study contributes to mapping the subfield, identifying challenges and areas for international collaboration, in a region where tourism experiences constant growth and is highly dependent on women's labour. From a policy standpoint, results call for increased institutional support for the production of gender-aware knowledge to transform prevailing social and gender inequalities.

\section{Methodology}

Bibliometric analysis is undertaken to provide a "profile" (Tsang and Hsu, 2011) of the gender and tourism subfield, by answering questions like total production, what has been researched, where and how. Given the early stage of tourism gender scholarship in the 
region, research evolution and impact are left for future analysis. The study collected and analysed journal articles containing relevant keywords for the period 2001 to 2015, in the three largest Latin American databases: Redalyc, Scielo and Latindex. The databases collectively have access to over 7,500 online publications from 32 Ibero-American countries. The search was limited to journal articles that explored tourism and gender in Latin America, and excluded other documents like research notes, book reviews or conference proceedings, which is common practice in bibliometric studies (Small et al., 2017; FigueroaDomecq et al., 2015; Corral and Cànoves, 2013).

The main search terms were tourism or tourist, and gender. In addition, the search included a list of terms related to gender identities, sexuality and tourism, drawn from the authors' experience and the relevant literature (Henderson and Gibson, 2013; Pritchard et al., 2007; Swain, 2005). Bibliometric studies that employ lists of keywords allow for exhaustive searches in tourism and non-tourism journals, even though a drawback is to encounter some results that may not focus on tourism (Corral and Cànoves, 2013). The list of keywords is presented below. All terms were introduced in Spanish, Portuguese and English.

- women, men, female, male, children, girls, boys, feminine, masculine, homosexual, gay, lesbian, LGBT, queer, transgender, transsexual;

- enterprise, entrepreneur, cooperatives, business, hotel;

- handicraft, artisan, heritage;

- empowerment, change, transformation, participation, sustainability;

- body, embodiment, eroticism;

- migration, prostitution, sex tourism;

The process of article collection took place in November and December 2016. For Redalyc and Scielo, the list of terms was introduced in the fields of title, abstract and keywords. For Latindex, the authors limited the search to online journals by the subject of "Social Sciences" and sub-themes of "Tourism" (63 unique titles) and "Gender studies" (35 unique titles). The searches displayed some irrelevant results for the study. For example, the term handicraft showed studies that examined the production and sale of crafts for tourist consumption, but omitted a significant analysis of tourism processes. Authors discussed on a case-by-case basis whether articles that had an ambiguous relationship with tourism should be kept or not. For example, studies that discussed health issues in migration and prostitution, but did not examine tourism were eliminated. All duplicate articles were also eliminated. The resulting 153 papers from 70 journals were downloaded and saved for analysis. Both authors read the 153 articles and coded the following variables: year of publication, journal, authors, authors' affiliation (university, faculty and country), types of articles (empirical results, theoretical-conceptual), article topics, methodologies and geographical location of fieldwork. Coded data was entered into an Excel file to perform descriptive statistics.

\section{Results}

Publication dates and journals

The first articles on gender and tourism in the region were published in 2001. Production was anecdotal during the following three years, with some peaks in 2005 and 2007. The 
years that concentrate the highest production are 2015 with 32 papers, 2014 and 2010 with 21 papers each. Figure 1 shows the total number of gender and tourism papers published in Latin America for the period 2001-2015. The increase in gender aware production in the period 2010-2015 may respond to renewed calls to introduce a gender perspective in the academic and public policy contexts (Vizcaino-Suárez et al., 2014).

Over half of the papers (87 or $57 \%$ ) appeared in tourism and hospitality journals. Nearly a fourth of the papers (35 or $23 \%$ ) came up in social sciences and humanities journals (including sociology, cultural studies, anthropology, geography and history). Gender studies journals account for $8.5 \%$ of the papers (13) and health studies journals for $5.2 \%$ of the studies (8). Over a third of the 21 tourism and hospitality journals ( 8 or $38 \%$ ) have only published one gender aware paper. This may be an indicator of the marginal position of gender and tourism studies within the broader tourism scholarship. Two journals have been promoting the inclusion of gender and tourism research in Latin America and published 41 $(26.7 \%)$ of the papers in the subfield. The journal Estudios y Perspectivas en Turismo, edited by the most prominent tourism research centre in Argentina (CIET) takes the lead with 28 papers (18.3\%), including the articles from the 2015 special issue on sex tourism. The journal PASOS: Revista de Turismo y Patrimonio Cultural (Universidad de La Laguna, Spain) follows suit with 13 papers $(8.5 \%)$. Table 1 shows the top 10 journals for Latin American tourism and gender research.

Even though tourism and gender is an interdisciplinary subfield, over $90 \%$ of scholars ascribed to tourism faculties publish their work in tourism and hospitality journals. This is probably because research outputs are assessed in disciplinary commissions. Scholars ascribed to interdisciplinary programmes in the social sciences and the humanities are more prone to publishing in gender studies journals. Examples of these latter are Cadernos Pagu (Universidade Estadual de Campinas, Brazil) with 5 papers on tourism and gender; Revista La Ventana (Universidad de Guadalajara, Mexico) with 4 papers; or Revista Estudos Feministas (Universidade Federal de Santa Catarina, Brazil) with 3 papers. The main difference between the articles published in tourism journals from those published in gender studies journals is the research focus. The former have a specific focus on tourism processes, whereas the latter examine tourism as a complementary activity or in connection with broader social phenomena (e.g. migration, prostitution).

The majority of the studies analysed were published in Spanish (67\%), followed by Portuguese (29\%) and English (4\%). Concerning the institutional affiliation, 39\% of scholars work at Brazilian institutions, $26 \%$ at Mexican institutions and $8 \%$ at Argentinian institutions. There is a high percentage of solo authorship, accounting for $46 \%$ of the papers. Coauthorship is most prevalent in case of two authors (32\%), followed by three authors $(12 \%)$. Four or more authors accounts for $10 \%$ of the papers.

Tourism scholarship in Latin America ranks low in internationalisation indicators, including networks and knowledge transfer (Pearce, 2013). Among publications with co-authorship, $54 \%$ of the papers have more than one author from the same institution; $29 \%$ report authors working in two institutions; $9 \%$ from three institutions; and $2 \%$ from four or more institutions. Figueroa-Domecq et al. (2015) identified a similar pattern for the subfield of gender and tourism research in the Anglophone academies, with less than a fifth of papers resulting from multi-institutional collaboration. 
Findings do not show a particular preference among the few scholars participating in international co-authorship. Only 5 articles (3.2\%) were produced with European authors; 3 $(2 \%)$ with authors from the United States; and $3(2 \%)$ with authors from different Latin American institutions. Despite efforts to promote international networking in the past decade, inconsistent policies persist in the region. For example, the lack of external collaboration in Mexican universities responds to contradictory national policies that promote: a) working alone to consolidate an individual research trajectory; or b) working mostly with faculty members from the same university, to consolidate institutional academic bodies.

\section{Types of articles and methodologies}

The main theoretical approaches for gender and tourism research in Latin America derive from sociological and anthropological perspectives, rather than administrative or economic ones. The majority of papers (134 or $87.6 \%$ ) are empirical and focus on local or regional cases. The remaining 19 articles $(12.4 \%)$ are historical or theoretical studies. The lack of theoretical research is not unique to the subfield of gender and tourism; but rather reflects the embryonic state of tourism scholarship in the region (Barreto, 2004; Monterrubio, 2012; Niding and Andueza, 2010).

Table 2 displays the ranking of methodologies in the subfield, topped by qualitative methodologies (68.6\%), followed by quantitative $(11.1 \%)$ and mixed methods $(7.8 \%)$. These results stand in contrast with the wide use of quantitative methodologies in the bibliometric study of tourism gender research conducted by Figueroa-Domecq et al. (2015). There are practical reasons that limit the adoption of quantitative methodologies for gender and tourism research in Latin America. The most important restriction is the limited sources and divergent quality of gender statistics in the region (Milosavljevic, 2007). The lack of gender statistics in tourism is exacerbated at the local level and for informal tourism activities (UNWTO-ILO, 2014). Furthermore, qualitative methodologies have proven useful in the examination of gender relations and lived experience in the region. This trend is consistent with the international literature, where qualitative methodologies are employed in "critical studies of gender, colour, race, ethnicity, hybridity and the Other" (Wilson and Hollinshead, 2015 , p. 31). The bibliometric analysis conducted by Small et al. (2017) also showed a preponderance of qualitative methodologies in gender-aware research published in highranking tourism journals. The use of qualitative approaches is not limited to the subfield of gender and tourism, but has been documented across the field in top journals like Annals of Tourism Research (Nunkoo et al., 2017; Tribe and Xiao, 2011).

\section{Research topics and geographical location of fieldwork}

The topics in Latin American tourism gender research are summarised in Table 3, following the four categories established by Figueroa-Domecq et al. (2015) to facilitate international comparison (gendered hosts, gendered tourists, gendered labour, and theory). The subfield in Latin America has prioritised the analysis of gendered hosts (66.7\% of papers), showing particular interest on the gendered impacts of tourism in local communities, including changes in social and gender dynamics (33.3\%). The links between tourism and the global 
sex trade $(20.3 \%)$ are also relevant in a region with a history of colonisation, migration, sexual violence and exploitation of ethnic and Afro-descendant women and children. A fifth of the papers $(20.3 \%)$ deal with gendered tourists, which is the dominant category in the Anglophone academies (Figueroa-Domecq et al., 2015). There is recent concern for understanding the differentiated behaviour, decision-making and motivation of female and male tourists $(6.5 \%)$, and new tourist segments based on sexual diversity (gay, lesbian and transsexual tourism, 5.2\%). Articles that explore theory, research and education account for $7.2 \%$ of the total, focusing on conceptual and ethical debates on tourism, gender and sexuality. Finally, papers that deal with gendered labour (5.9\%), seek to characterise women's participation in formal and informal tourism employment in the region (3.9\%), rather than systematically measuring gender discrimination and occupational segregation $(1.3 \%)$.

Table 4 displays the geographical location and scope of fieldwork in Latin American tourism gender research. Over $70 \%$ of the papers examine local territories; $11.1 \%$ of the papers conduct fieldwork at the country-level; regional fieldwork involving two or three Latin American countries accounts for $2.6 \%$ of the papers; and $2.6 \%$ of the papers conduct fieldwork in international tourism circuits (Latin America - Europe). A closer examination shows interest in the interactions between tourism and gender in consolidated and emerging coastal destinations that attract international tourists (30.7\%); large and medium-sized urban centres that receive international or intra-regional tourism flows (17.6\%); rural and indigenous communities with rich cultural heritage (17\%); and protected areas that offer opportunities for ecotourism or adventure tourism (5.2\%).

\section{Discussion}

\section{Common and divergent trends in tourism gender research}

The bibliometric analysis shows that tourism gender research in Latin America is in an embryonic stage, compared to the more diverse and theoretically mature subfield in the international academy. This is partially explained by the relatively recent introduction of gender as an analytical category in Latin American tourism scholarship (at the beginning of the $21^{\text {st }}$ century), not due to a lack of feminist or gender frameworks in the region. The increase in tourism gender studies for the period 2010-2015 likely responds to renewed calls for the introduction of gender perspectives in the academic and policy contexts (VizcainoSuárez et al., 2014), and could pave the way for future growth. So far, Latin American academies have contributed to knowledge on gender and tourism through the analysis of power tensions between hegemonic and marginalised groups who seek opportunities in tourism development, revealing the interconnections between socioeconomic, gender and ethnic inequalities. Scholars in the region have also advanced the critical analysis of gender and tourism work, paying particular attention to the fundamental yet undervalued care work performed by women in the tourism and hospitality industries.

Common topics with the international literature include the gendered impacts of tourism in host communities, mainly development, sustainability and social change (e.g. Lunardi et al., 2015; Rodríguez and Acevedo, 2015); and the links between tourism and the global sex trade from the perspective of gendered hosts (e.g. Cáceres et al. 2015; Mendoza, 2015). The topic of gendered tourists (particularly female travellers) has received less attention 
relative to the Anglophone academies. This is probably because policies in Latin America have adopted tourism as a strategy for development, prioritising international tourism over domestic or intra-regional flows (Ghimire, 2013). Countries in the region are slowly realising the enormous potential of domestic and regional travel markets (e.g. SECTUR, 2013), which may ignite academic interest on Latin American travellers.

Another trend is the use of binary gender categories (female/male) in the Latin American scholarship ( $87 \%$ of the papers). Brazilian scholars have been more prone to studying nonheteronormative gender identities and sexualities ( 6 out of 8 articles), by critically examining the construction of tourist destinations as exotic and sensual places. The incorporation of a broader set of categories that intersect with racial, ethnic and class inequalities, gender identities and sexualities, could strengthen knowledge production in the subfield.

\section{Challenges and future directions for the subfield}

This study confirms the peripheral position of tourism gender research in Latin America. Some of the challenges for gender aware scholarship have been discussed in the Anglophone academies (Figueroa-Domecq et al., 2015; Small et al., 2017). These include:

a. Structural inequalities in higher education that limit women's participation in leadership positions (Munar et al., 2015);

b. Male, positivist and industry-oriented approaches in business schools, where the majority of tourism programmes are inserted (Pritchard and Morgan, 2007); and

c. Disarticulation between tourism gender studies and broader critical and feminist debates in the social sciences (Figueroa-Domecq et al., 2017).

We add to the discussion by contextualising the difficulties faced by tourism gender scholars in Latin America. The region has one of the highest rates of women in science: $45 \%$ compared to the world average of $30 \%$ (MINCYT, 2015). Despite these advances, Latin American universities continue to promote patriarchal policies and views of science (Lagarde, 2000). Gender inequalities are particularly evident at the highest levels of academia (Ordorika, 2015). Basurto-Barcia and Ricaurte-Quijano (2016) examined gender inequalities in tourism academia in Guayaquil, Ecuador. The authors found that women were more likely to have permanent teaching posts and produce research, whilst men tended to occupy the top positions in conference committees and academic departments (pp. 263-65). Future studies could expand the geographical scope and variables of analysis (e.g. journal founders or editorial boards) to provide a comprehensive picture of women's position in Latin American tourism academies.

Tourism programmes in Latin American public universities tend to belong to social science faculties instead of business schools, which is the norm in Anglophone countries. This opens opportunities for critical scholars to engage in interdisciplinary research that examines tourism's intersections with other spheres of life (e.g. heritage, traditional activities, leisure and wellbeing). We can learn from the experience of social science and gender studies scholars who have built on heterogeneous theoretical and methodological frameworks, to create interdisciplinary areas of research, favouring the exchange between theory and practice (Femenías, 2009, p. 53). 
Finally, there is need for increased international collaboration between critical, feminist and tourism gender scholars. This would allow scholars in the Anglophone and Latin American academies to create synergies by contrasting theoretical propositions in a diverse range of settings; promoting situated gender knowledge; challenging Eurocentric or postcolonial views; and exchanging strategies to overcome institutional or research-specific obstacles in the subfield. Scholars across regions can take advantage of information and communication technologies that facilitate virtual collaboration, to exchange information, engage in transnational projects (including comparative studies) or participate in international coauthorship. Increased collaboration would not only contribute to diminish the sense of isolation among tourism gender scholars, but to advance common areas of interest for more just, inclusive and diverse tourism academies.

\section{References}

Apostolopoulos, Y., Sönmez, S. and Timothy, D. (Eds.) (2001), Women as producers and consumers of tourism in developing regions, Praeger, Westport, CT.

Barreto, M. (2004), "Produção científica na área de turismo", in Moesch, M.M. and Gastal, S. (Eds.), Um Outro Turismo é Possível, Contexto, São Paulo, Brazil, pp.83-88.

Basurto-Barcia, J. and Ricaurte-Quijano, C. (2016), "Mujeres en turismo: Equidad de género en la docencia e investigación en el área de Guayaquil, Ecuador", Estudios y perspectivas en turismo, Vol. 25 No. 3, pp. 255-78.

Baum, T. (2013), International perspectives on women and work in hotels, catering and tourism. International Labour Organization, Geneva.

Bergareche, A. and Vargas, E. (2010), "Nuevos desafíos, renovadas miradas: algunas propuestas al debate sobre género, desarrollo y turismo en el Pacífico mexicano", Revista México y la Cuenca del Pacífico, Vol. 13 No. 37, pp. 75-102.

Berger, D. (2006), The Development of Mexico's Tourism Industry: Pyramids by Day, Martinis by Night, Palgrave McMillan, New York, NY.

Cáceres, C. F., Nureña, C. R. and Gomero, A. (2015), "La oferta de trabajo sexual masculino en el Perú: Su interacción con las demandas del turismo internacional", Estudios y perspectivas en turismo, Vol. 24 No. 4, 924-42.

Capanegra, C. A. (2008), "La invención del desarrollo turístico. Genealogía de una episteme de poder", in César-Dachary, A. and Arnaiz-Burne, S.M. (Eds.), Turismo y Desarrollo: Crecimiento y Pobreza, Universidad de Guadalajara, Universidad de Buenos Aires, Universidad Nacional de Mar del Plata, Ediciones de la Noche, México, pp. 109-134.

Carosio, A. (2012), Feminismo y cambio social en América Latina y el Caribe, 1a ed., CLACSO, Buenos Aires. 
Castillo, M. and Panosso, A. (2011), "Implicaciones epistemológicas en la investigación turística”, Estudios y perspectivas en turismo, Vol. 20 No. 2, pp. 384-403.

Cohen, E. and Cohen, S. A. (2015), "Beyond Eurocentrism in tourism: A paradigm shift to mobilities", Tourism Recreation Research, Vol. 40 No. 2, pp. 157-68.

Corral, J. A. and Cànoves, G. (2013), "La investigación turística publicada en revistas turísticas y no turísticas: análisis bibliométrico de la producción de las universidades catalanas", Cuadernos de Turismo, Vol. 31, pp. 55-81.

Díaz-Carrión, I. A. (2010), "Ecoturismo comunitario y género en la reserva de la biosfera de los Tuxtlas (México)", PASOS. Revista de Turismo y Patrimonio Cultural, Vol. 8 No. 1, pp. 151-65.

Díaz-Carrión, I. A. (2012), "Turismo de aventura y participación de las mujeres en Jalcomulco (México)", PASOS. Revista de Turismo y Patrimonio Cultural, Vol. 10 No. 5, pp. $531-42$.

Duffy, L. N., Kline, C. S., Mowatt, R. A. and Chancellor, H. C. (2015), "Women in tourism: Shifting gender ideology in the DR", Annals of Tourism Research, Vol. 52, pp. 72-86.

Economic Commission for Latin America and the Caribbean (ECLAC). (2016), Equality and Women's Autonomy in the Sustainable Development Agenda, available at: http://repositorio.cepal.org/bitstream/handle/11362/40675/1/S1600898 en.pdf (accessed 10 November 2016).

Femenías, M.L. (2009). "Género y feminismo en América Latina”, Debate Feminista, Vol. 40, pp. 42-74.

Ferguson, L. (2011), "Promoting gender equality and empowering women? Tourism and the third Millennium Development Goal”, Current Issues in Tourism, Vol. 14 No. 3, pp. 235-49.

Ferguson, L. and Moreno, D. (2015), "Gender and sustainable tourism: Reflections on theory and practice", Journal of Sustainable Tourism, Vol. 23 No. 3, pp. 401-16.

Ferreira Freire Guimarães, C. R. and Ramos Silva, J. (2016), "Pay gap by gender in the tourism industry of Brazil", Tourism Management, Vol. 52, pp. 440-50.

Figueroa-Domecq, C., Pritchard, A., Segovia-Pérez, M., Morgan, N. and Villacé-Molinero, T. (2015), "Tourism gender research: A critical accounting", Annals of Tourism Research, Vol. 52, pp. 87-103.

Ghimire, K. B. (2013), The native tourist: Mass tourism within developing countries, Routledge, London, UK.

Gibson, H. (2001), "Gender in tourism: Theoretical perspectives", in Apostolopoulos, Y., Sönmez, S. and Timothy, D.J. (Eds.), Women as producers and consumers of tourism in developing regions, Praeger, Westport, CT, pp. 19-43. 
Guevara-Ramos, R., Molina, S. and Tresserras, J. (2006), "Hacia un estado de la cuestión en investigación turística", in Guevara-Ramos, R. (Ed.), Estudios multidisciplinarios en turismo, Volumen 1, Secretaría de Turismo, Mexico, pp. 17-64.

Hall, D., Swain, M. B. and Kinnaird, V. (2003), "Tourism and gender: An evolving agenda", Tourism Recreation Research, Vol. 28 No. 2, pp. 7-11.

Henderson, K. and Gibson, H. (2013), "An integrative review of women, gender, and leisure: Increasing complexities", Journal of Leisure Research, Vol. 45, No. 2, 115-35.

Huete, R., Brotons, M. and Sigüenza, M. C. (2016), "La desigualdad entre mujeres y hombres en el sector hostelero español", Estudios y Perspectivas en Turismo, Vol. 25 No. 1, pp. 73-87.

Kinnaird, V. and Hall, D. R. (Eds.) (1994), Tourism: A gender analysis, Wiley, Chichester, UK.

Lunardi, R., de Souza, M. and Perurena, F. (2015), "O trabalho de homens e mulheres no Turismo Rural em São José dos Ausentes: o 'leve' e o 'pesado'”, Turismo-Visão e Ação, Vol. 17 No. 1, pp. 179-209.

Martínez, O. F. (Ed.) (2005), Desarrollo sustentable: Turismo, costas y educación, Universidad de Quintana Roo, Chetumal, Mexico.

Mendoza, C. (2015), "Entre el negocio y el placer: Turismo sexual masculino en Puerto Vallarta, México", Estudios y perspectivas en turismo, Vol. 24 No. 4, pp. 889-907.

Milosavljevic, V. (2007), Estadísticas para la equidad de género. Magnitudes y tendencias en América Latina, Comisión Económica para América Latina y el Caribe, CEPAL, Santiago, Chile.

Ministerio de Ciencia, Tecnología e Innovación Productiva (MINCYT) (2015). "Argentina, distinguida por la igualdad de género en ciencia”, available at: http://www.mincyt.gob.ar/noticias/argentina-distinguida-por-la-igualdad-de-genero-enciencia-11271 (accessed 20 December, 2016).

Monterrubio, J. C. (2012), "Questioning the maturity of tourism research: a Mexican perspective", Revista de Management de la Universidad de Palermo, No. 6, pp. 73-82.

Munar, A.M. et al. (2015), "The Gender Gap in the Tourism Academy: Statistics and Indicators of Gender Equality. While Waiting for the Dawn", available at: http://research.cbs.dk/files/45082310/ana maria munar the gender gap.pdf (accessed 20 December, 2016).

Niding, M. and Andueza, J. (2010), "Campo y Habitus en las Investigaciones sobre el Turismo", Aportes y Transferencias, Vol. 14 No. 2, pp. 79-94. 
Norris, J. and Wall, G. (1994), "Gender and tourism", in Cooper, C. P. and Lockwood, A. (Eds.), Progress in tourism, recreation and hospitality management, Volume 6, John Wiley \& Sons, New York, NY, pp. 57-78.

Nunkoo, R., Hall, C. M. and Ladsawut, J. (2017), "Gender and choice of methodology in tourism social science research", Annals of Tourism Research, Vol. 63, pp. 207-10.

Ordorika, I. (2015). Equidad de género en la Educación Superior. Revista de la educación superior, 44(174), 7-17.

Pearce, D. (2013), "Comprometiéndose con el Mundo: América Latina y la Internacionalización de la Investigación en Turismo", Estudios y perspectivas en turismo, Vol. 22 No. 5, pp. 908-25.

Phommavong, S. and Sörensson, E. (2014), "Ethnic tourism in Lao PDR: gendered divisions of labour in community-based tourism for poverty reduction", Current issues in tourism, Vol. 17 No. 4 , pp. $350-62$.

Pritchard, A. and Morgan, N. (2000), "Privileging the male gaze: Gendered tourism landscapes”, Annals of Tourism Research, Vol. 27 No. 4, pp. 884-905.

Pritchard, A. and Morgan, N. (2007), "De-centring tourism's intellectual universe or the dialectic between change and tradition", in, Ateljevic, I., Pritchard, A. and Morgan, N. (Eds.), The Critical Turn in Tourism Studies, Elsevier, Oxford, UK, pp. 12-28.

Pritchard, A., Morgan, N., Ateljevic, I. and Harris, C. (Eds.) (2007), Tourism and gender: embodiment, sensuality and experience, CABI International, Oxforshire, UK.

Rodríguez, G. and Acevedo, A. (2015), "Cambios en la vida cotidiana de las mujeres a través de la incorporación al trabajo turístico en la Reserva de la Biosfera de la Mariposa Monarca", El Periplo Sustentable, No. 29, available at: http://www.redalyc.org/jatsRepo/1934/193440418008/193440418008 visor jats.pdf (accessed 20 May 2017).

Salazar, N. B. (2006), "Antropología del turismo en países en desarrollo: análisis crítico de las culturas, poderes e identidades generados por el turismo", Tabula rasa, Vol. 5, pp. 99128.

Schlüter, R. and Bertoncello, R. (2010), "Tourism Research in Latin America: Past and Future Challenges", in Pearce D.G. and Butler R.W. (Eds.), Tourism Research: A 20/20 Vision, Goodfellow, Oxford, UK, pp. 135-46.

Secretaría de Turismo de México (SECTUR) (2013), "Encuesta Nacional de Gasto en Turístico en los Hogares", available at: http://www.datatur.sectur.gob.mx/Documentos\%20Publicaciones/ENGATURH 2013.pdf (accessed 20 May 2017). 
Serrano-Barquín, R.C. (2008), "Hacia un modelo teórico-metodológico para el análisis del desarrollo, la sostenibilidad y el turismo", Economía, sociedad y territorio, Vol. 8 No. 26, pp. 313-55.

Sinclair, M. T. (Ed.) (1997), Gender, work and tourism, Routledge, London, UK.

Small, J., Harris, C. and Wilson, E. (2017), "Gender on the agenda? The position of gender in tourism's high ranking journals", Journal of Hospitality and Tourism Management, Vol. 31, pp. 114-17.

Swain, M. B. (1995), "Gender in tourism”, Annals of tourism research, Vol. 22 No. 2, pp. 24766.

Swain, M. B. (2005), "Las dimensiones de género en la investigación sobre turismo: Temas globales, perspectivas locales”, Política y sociedad, Vol. 42 No. 1, pp. 25-37.

Swain, M. B. and Momsen, J. H. (Eds.) (2002), Gender/tourism/fun (?), Cognizant Communication Corporation, New York.

Tribe, J. and Xiao, H. (2011), "Developments in tourism social science", Annals of Tourism Research, Vol. 38 No. 1, pp. 7-26.

Tsang, N. K. and Hsu, C. H. (2011), "Thirty years of research on tourism and hospitality management in China: A review and analysis of journal publications", International Journal of Hospitality Management, Vol. 30 No. 4, pp. 886-96.

Tucker, H. and Boonabaana, B. (2012), "A critical analysis of tourism, gender and poverty reduction”, Journal of Sustainable Tourism, Vol. 20 No. 3, pp. 437-55.

United Nations World Tourism Organization. (2011), Global Report on Women in Tourism 2010, UNWTO, Madrid.

United Nations World Tourism Organization. (2016), Tourism Highlights 2016, UNWTO, Madrid.

United Nations World Tourism Organization and International Labour Organization. (2014), Measuring Employment in the Tourism Industries - Guide with Best Practices, UNWTO, Madrid.

Vizcaino-Suárez, L.P., Serrano-Barquín, R., Cruz-Jiménez, G. and Pastor-Alfonso, M.J. (2014), "El género en la investigación y las políticas turísticas en México", paper presented at the XVIII Congreso de la Asociación Española de Expertos Científicos en Turismo (AECIT), 26-28 November, Benidorm, Spain, available at: http://www.aecit.org/el-genero-enla-investigacion-y-las-politicas-turisticas-en-mexic/congress-papers/67/ (accessed 20 May 2017). 
Vizcaino-Suárez, L.P, Serrano-Barquín, R., Cruz-Jiménez, G. and Pastor-Alfonso, M.J. (2016), "Teorías y métodos en la investigación sobre turismo, género y mujeres en Iberoamérica: Un análisis bibliográfico", Cuadernos de Turismo, No. 38, pp. 485-501.

Wilson, E. and Hollinshead, K. (2015), "Qualitative tourism research: Opportunities in the emergent soft sciences”, Annals of Tourism Research, Vol. 54, pp. 30-47. 
Figure 1 Graph of gender and tourism papers published by year, 2001-2015

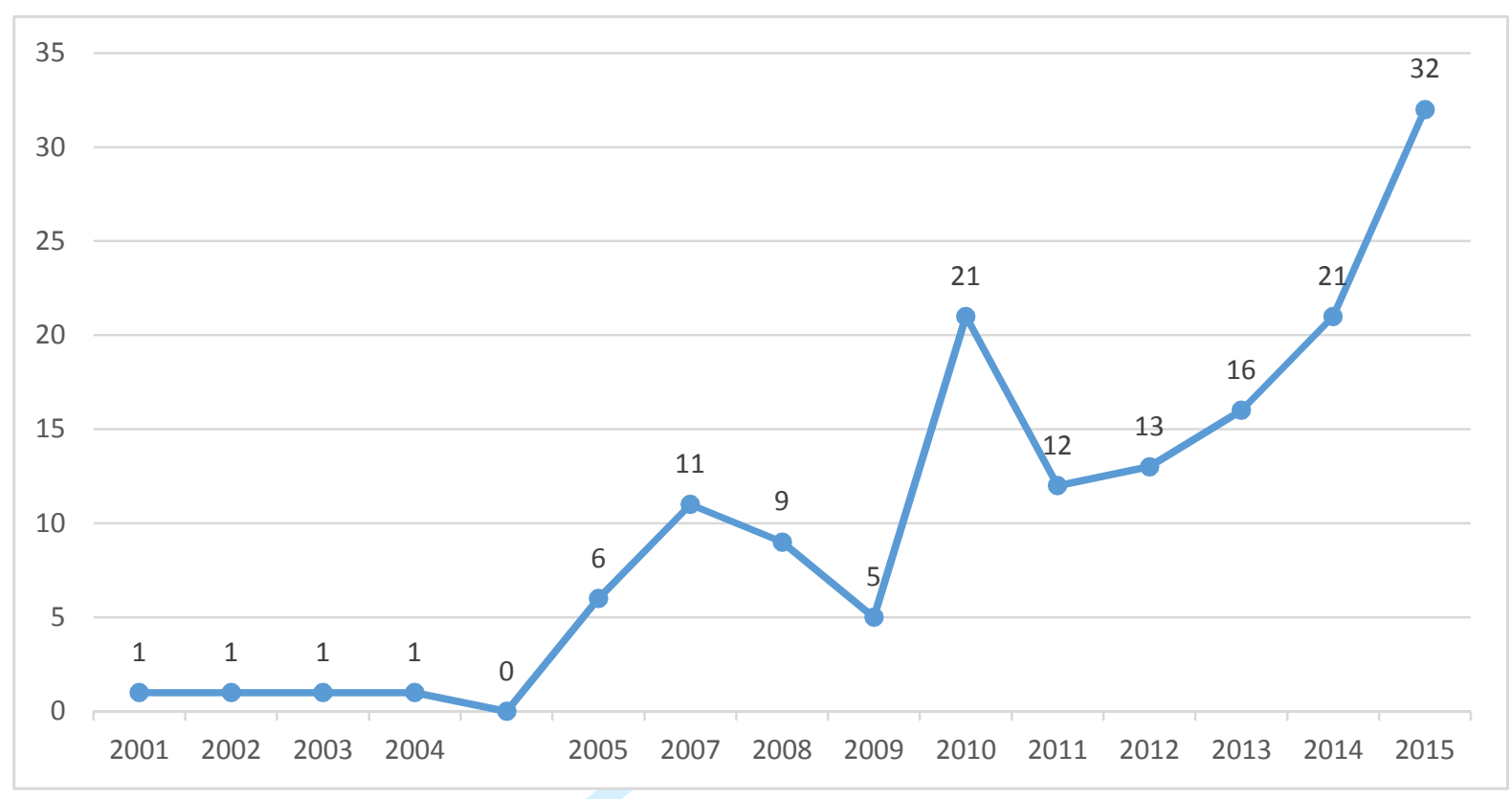

1

2

4

5

6

7

8

9

10

11

12

14

15

16

17

18

19

20

21

22

23

24

25

26

27

28

29

30

31

32

33

34

35

36

37

38

39

40

41

42

43

44

45

46

47

48

49

50

51

52

53

54

55

56

57

58

59

60 
Table 1

Top 10 journals for Latin American tourism and gender research

\begin{tabular}{cllr}
\hline & Journal & Country & No. of \\
\hline 1 & Estudios y Perspectivas en Turismo & Argentina & 28 \\
2 & PASOS: Revista de Turismo y Patrimonio Cultural & Spain & 13 \\
3 & Turismo em Análise & Brazil & 6 \\
4 & Turismo - Visão e Ação & Brazil & 5 \\
5 & Cadernos Pagu (Gender studies) & Brazil & 5 \\
6 & Rosa dos Ventos & Brazil & 5 \\
7 & Cenário & Brazil & 4 \\
8 & La Ventana: Revista de Estudios de Género & Mexico & 4 \\
9 & Teoría y Praxis & Mexico & 4 \\
10 & TURyDES & Spain & 4 \\
& & Total & 78
\end{tabular}




\section{Page 17 of 22}

1
2
3
4
5
6
7
8
9
10
11
12
13
14
15
16
17
18
19
20
21
22
23
24
25
26
27
28
29
30
31
32
33
34
35
36
37
38
39
40
41
42
43
44
45
46
47
48
49
50
51
52
53
54
55
56
57
58
60

\begin{tabular}{cc}
\hline papers & \% of all papers \\
\hline 18.3 \\
8.5 \\
3.9 \\
3.3 \\
3.3 \\
3.3 \\
2.6 \\
2.6 \\
2.6 \\
2.6 \\
51.0
\end{tabular}


Table 2

Methodologies in Latin American tourism and gender research

\begin{tabular}{lr}
\hline Methodology & No. of \\
\hline Qualitative & 105 \\
Ethnographic methods (observation, fieldwork diaries, interviews, oral history) & 82 \\
Critical discourse analyisis of secondary sources, websites, film, photographs & 15 \\
Case study & 5 \\
Participatory Action Research & 2 \\
Delphi & 1 \\
Theoretical / historical analysis & 19 \\
Theoretical & 15 \\
Historical analysis & 15 \\
Quantitative & 4 \\
Descriptive statistics & 17 \\
Chi-square & 9 \\
Logit models & 2 \\
Composite index & 2 \\
Nonparametric & 1 \\
Time series analyisis & 1 \\
Mixed methods & 1 \\
Total & 12
\end{tabular}




1
2
3
4
5
6
7
8
9
10
11
12
13
14
15
16
17
18
19
20
21
22
23
24
25
26
27
28
29
30
31
32
33
34
35
36
37
38
39
40
41
42
43
40
45
49
50
50
51
53
55
50

\begin{tabular}{rr}
\hline papers & \% of papers \\
\hline 68.6 \\
53.6 \\
9.8 \\
3.3 \\
1.3 \\
0.7 \\
12.4 \\
9.8 \\
2.6 \\
11.1 \\
5.9 \\
1.3072 \\
1.3072 \\
0.6536 \\
0.6536 \\
0.6536 \\
7.8 \\
100
\end{tabular}




\section{Table 3}

Topics in Latin American tourism and gender research

Research Topic

Gendered hosts

Tourism, gender and development

Sex tourism, sexual violence and exploitation

Gendered images in tourism promotion

Tourism and public health

Entrepreneurship

Residents' attitudes and perceptions

Gendered tourists

Consumer behaviour, decision-making and motivation

Gay, lesbian and transexual tourism

Sex/romance tourism

Historical accounts of women in tourism

Perceptions of tourism destination and product images

Risk perception

Theory, research and education

Tourism, gender and theory

Ethical debates

Tourism biographies/historiographies

Tourism policy

Tourism education

Gendered labour

Women's participation in tourism employment

Gender discrimination and occupational segregation

Political leadership

Total 


1
2
3
4
5
6
7
8
9
10
11
12
13
14
15
16
17
18
19
20
21
22
23
24
25
26
27
28
29
30
31
32
33
34
35
36
37
38
39
40
41
42
43
44
45
46
47
48
49
50
51
52
53
54
55
56
57
50

\begin{tabular}{|c|c|}
\hline No. of papers & $\%$ of papers \\
\hline 102 & 66.7 \\
\hline 51 & 33.3 \\
\hline 31 & 20.3 \\
\hline 8 & 5.2 \\
\hline 5 & 3.3 \\
\hline 4 & 2.6 \\
\hline 3 & 2.0 \\
\hline 31 & 20.3 \\
\hline 10 & 6.5 \\
\hline 8 & 5.2 \\
\hline 6 & 3.9 \\
\hline 3 & 2.0 \\
\hline 3 & 2.0 \\
\hline 1 & 0.7 \\
\hline 11 & 7.2 \\
\hline 5 & 3.3 \\
\hline 2 & 1.3 \\
\hline 2 & 1.3 \\
\hline 1 & 0.7 \\
\hline 1 & 0.7 \\
\hline 9 & 5.9 \\
\hline 6 & 3.9 \\
\hline 2 & 1.3 \\
\hline 1 & 0.7 \\
\hline 153 & 100 \\
\hline
\end{tabular}


Table 4

Geographical location and scope of fieldwork in Latin American tourism gender research

\begin{tabular}{lcc}
\hline Location / scope of fieldwork & No. of papers & \% of papers \\
\hline Local territories & 108 & 70.6 \\
Coastal-Marine & 47 & 30.7 \\
Urban & 27 & 17.6 \\
Rural & 26 & 17.0 \\
Wilderness \& Protected Areas & 8 & 5.2 \\
No Location & 20 & 13.1 \\
Theoretical-conceptual & 13 & 8.5 \\
Text or media analysis & 6 & 3.9 \\
Undisclosed - ethical concerns & 1 & 0.7 \\
National & 17 & 11.1 \\
Country level & 10 & 6.5 \\
Several locations within country & 7 & 4.6 \\
Regional & 4 & 2.6 \\
Two Latin American countries & 3 & 2.0 \\
Three Latin American countries & 1 & 0.7 \\
International & 4 & 2.6 \\
International circuit (Latam-Europe) & 2 & 1.3 \\
Internet & 2 & 1.3 \\
Total & 153 & 100
\end{tabular}

